\title{
Reclassification of the Cryptococcus humicola complex
}

1 Japan Collection of Microorganisms, RIKEN (The Institute of Physical and Chemical Research), Wako, Saitama 351-0198, Japan

2 Department of Microbiology, Meiji Pharmaceutical University, 2-522-1 Noshio, Kiyose, Tokyo 204-8588, Japan

\author{
Masako Takashima, ${ }^{1}$ Takashi Sugita, ${ }^{2}$ Takako Shinoda ${ }^{2}$ \\ and Takashi Nakase ${ }^{1} \dagger$
}

Author for correspondence: Masako Takashima. Tel: +81 48467 9560. Fax: +81484624617.
e-mail: masako@jcm.riken.go.jp

Ten strains of the Cryptococcus humicola complex were reclassified on the basis of sequence analyses of $18 \mathrm{~S}$ rDNA and internal transcribed spacer regions and DNA-DNA reassociation experiments. They were differentiated into seven species including C. humicola. Five novel species are proposed: Cryptococcus daszewskae sp. nov. (type strain CBS 5123 ${ }^{\top}=\mathrm{JCM}^{11166^{\top}}=$ MUCL 30649 $^{\mathrm{T}}$ ),

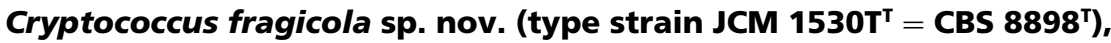
Cryptococcus longus sp. nov. (type strain CBS 5920 $=$ JCM 11167 ${ }^{\top}=$ MUCL $30690^{\top}$ ), Cryptococcus musci sp. nov. (type strain JCM 1531 ${ }^{\top}=$ CBS 8899') and Cryptococcus pseudolongus sp. nov. (type strain JCM 9712 ${ }^{\mathrm{T}}=$ CBS 8297'). A syntype of Sporobolomyces albidus JCM $1460^{\top}$ is also revealed to be a distinct species; the name Cryptococcus ramirezgomezianus nom. nov. is therefore proposed for Sporobolomyces albidus Ramírez Gómez (type strain IJFM $502^{\top}=$ CBS $2839^{\top}=J^{\prime} C^{2} 1460^{\top}=$ NRRL Y-2478'), since the name Cryptococcus albidus (Saito) C. E. Skinner has already been recognized for a distinct species within the genus Cryptococcus. Strains possessing either Q-9 or Q-10 have been reported to occur in $C$. humicola; however, after reclassification, the ubiquinone type of the species in each phylogenetic group was shown to be uniform, indicating that it is a useful criterion for the taxonomy of the Trichosporonales.

Keywords: novel species, Cryptococcus humicola complex, reclassification, Sporobolomyces albidus, internal transcribed spacer (ITS)

\section{INTRODUCTION}

Cryptococcus humicola (Daszewska) Golubev has been isolated from various substrates such as plants, soil and clinical specimens (Fell \& Statzell-Tallman, 1998). This species has been reported to be heterogeneous on the basis of the wide range of $\mathrm{G}+\mathrm{C}$ contents of nuclear DNA, the occurrence of both ubiquinone types Q-9 and Q-10 and the results of whole-cell protein electrophoresis (Nakase \& Komagata, 1971; Vancanneyt et al., 1994; Yamada \& Kondo, 1972). Phylogenetically, the species showed a close relationship to Cryptococcus

\footnotetext{
†Present address: Yothi Research Unit, National Center for Genetic Engineering and Biotechnology (BIOTEC), National Science and Technology Development Agency, 73/1 Rama VI Road, Bangkok 10400, Thailand.

Abbreviation: ITS, internal transcribed spacer.

The GenBank/EMBL/DDBJ accession numbers for the sequences determined in this study are AB051045-AB051048.
}

curvatus (Diddens et Lodder) Golubev and to Trichosporon species (Fell et al., 2000; Takashima \& Nakase, 1999). When Fell et al. (2000) proposed the order Trichosporonales, they did not include this species because of its low bootstrap value to the Trichosporonales based on the D1/D2 region of $26 \mathrm{~S}$ rDNA sequences (651 bp). However, Takashima \& Nakase (1999) reported that C. humicola was included in the Trichosporon lineage with a high bootstrap value for 18S rDNA sequences (1609 bp).

Recently, we reported a high degree of intraspecific heterogeneity in $C$. humicola on the basis of the sequences of $18 \mathrm{~S}$ rDNA and internal transcribed spacer (ITS) regions (Sugita et al., 2000). Of 16 strains, including the type strain, that appeared in that paper, five were confirmed to belong to C. humicola and two were identified as C. curvatus and Cryptococcus podzolicus (Bab'eva et Reshetova) Golubev. Eight strains were suspected to be undescribed species. We found 
that three of these strains produced arthroconidia and two novel species in the genus Trichosporon have been proposed to accommodate them (Sugita et al., 2001). The remaining five strains were shown to be divergent on the basis of sequence analyses of the 18S rDNA and ITS regions. Furthermore, two strains were reported to contain Q-10 and one strain had Q-9 as the major ubiquinone (Yamada \& Kondo, 1972; Vancanneyt et al., 1994). The CoQ system of the remaining two strains has not yet been determined. This report represents a systematic study to clarify the taxonomic position of these strains. In addition, a further strain of Cryptococcus sp., which was reported to be close to $C$. humicola on the basis of physiological and biochemical properties (Nakase et al., 1996), was included. These strains were shown to be different from $C$. humicola and were reclassified into six distinct species. After reclassification of the $C$. humicola complex, the ubiquinone type of each phylogenetic cluster was recognized to be uniform. A discussion is included of the taxonomic significance of the ubiquinone type in the Trichosporonales.

\section{METHODS}

Yeast strains. The strains used in this study are listed in Table 1. Nine strains were stock cultures identified as $C$. humicola in the Centraalbureau voor Schimmelcultures (CBS) collection, The Netherlands, and the Japan Collection of Microorganisms (JCM), Japan. Of these, strains CBS $5123^{\mathrm{T}}$, CBS $5290^{\mathrm{T}}$, JCM $1460^{\mathrm{T}}$, JCM $1530^{\mathrm{T}}$ and JCM $1531^{\mathrm{T}}$ were suggested in a previous paper to be undescribed species (Sugita et al., 2000). One strain, Cryptococcus sp. JCM
$9712^{\mathrm{T}}$, which was isolated from a dead tree as a cellulolytic yeast (Nakase et al., 1996), was also included in this study.

\section{Morphological, physiological and biochemical characteristics.} Most of the morphological, physiological and biochemical characteristics were examined according to Yarrow (1998). The assimilation of nitrogen compounds was investigated on solid media using starved inoculum. Vitamin requirements were determined according to the method of Komagata \& Nakase (1967). The maximum growth temperature was determined in YM broth (Difco) using thermoregulated metal block baths.

Major ubiquinone. Cells were grown in $500 \mathrm{ml}$ Erlenmeyer flasks containing $250 \mathrm{ml}$ YM broth on a rotary shaker at 150 r.p.m. at $25^{\circ} \mathrm{C}$ and were harvested in the early stationary growth phase. The cells were washed with distilled water. Extraction, purification and identification of ubiquinones were carried out according to the method of Nakase \& Suzuki (1986).

DNA base composition and DNA-DNA relatedness. Cells were grown in $500 \mathrm{ml}$ Erlenmeyer flasks containing $250 \mathrm{ml}$ YM broth on a rotary shaker at 150 r.p.m. at $25^{\circ} \mathrm{C}$ and were harvested in the exponential growth phase. The cells were washed with distilled water and freeze-dried. Isolation and purification of nuclear DNA were done according to Takashima \& Nakase (2000). The DNA base composition was determined by HPLC after enzymic digestion of DNA to deoxyribonucleosides as described by Tamaoka \& Komagata (1984). The DNA-GC kit (Yamasa Shoyu) was used as the quantitative standard. DNA-DNA reassociation experiments were carried out using the membrane-filter method of Hamamoto \& Nakase (1995).

Sequencing and phylogenetic analysis of $18 \mathrm{~S}$ rDNA. The nucleotide sequences of $18 \mathrm{~S}$ rDNA and ITS regions, in-

Table 1. Strains used in this study

\begin{tabular}{|c|c|c|c|}
\hline Strain & Other designation(s) & Source & $\begin{array}{c}\text { Major } \\
\text { ubiquinone* }\end{array}$ \\
\hline \multicolumn{4}{|l|}{ Cryptococcus humicola } \\
\hline $\mathrm{JCM} 1457^{\mathrm{T}} \dagger$ & $\begin{array}{l}=\text { ATCC } 14438^{\mathrm{T}}=\text { CBS } 571^{\mathrm{T}} \\
=\mathrm{IGC} 3387^{\mathrm{T}}=\text { MUCL } 29840^{\mathrm{T}} \\
=\text { NCYC } 818^{\mathrm{T}}=\text { NRRL Y-12944 }\end{array}$ & Soil & $\mathrm{Q}^{a}$ \\
\hline JCM 1459 & $\begin{array}{l}=\text { ATCC } 9949=\text { CBS } 2041 \\
=\text { DSM } 6382=\text { IFO } 0753 \\
=\text { NRRL Y-1266 }\end{array}$ & $\begin{array}{l}\text { Culture of Sachsia suaveolens } \\
\text { Lindner }\end{array}$ & $\mathrm{Q}^{a}$ \\
\hline JCM 1461 & $=$ CBS $4280=$ MUCL 30648 & Surface of Amanita muscaria & ND \\
\hline JCM 9575 & - & Soil & ND \\
\hline Cryptococcus daszewskae CBS $5123^{\mathrm{T}}$ & $=\mathrm{JCM} 11166^{\mathrm{T}}=\mathrm{MUCL} 30649^{\mathrm{T}}$ & Skin & $\mathrm{Q} 10^{b}$ \\
\hline Cryptococcus fragicola JCM $1530^{\mathrm{T}}$ & $=\mathrm{CBS} 8898^{\mathrm{T}}$ & Strawberry & Q10 ${ }^{a}$ \\
\hline Cryptococcus longus CBS $5920^{\mathrm{T}}$ & $=\mathrm{JCM} 11167^{\mathrm{T}}=\mathrm{MUCL} 30690^{\mathrm{T}}$ & Radioactive solution at $\mathrm{pH} 2$ & $\mathrm{Q}^{d}$ \\
\hline Cryptococcus musci JCM $1531^{\mathrm{T}}$ & $=\mathrm{CBS} 8899^{\mathrm{T}}$ & Moss & $\mathrm{Q}^{a}$ \\
\hline Cryptococcus pseudolongus JCM $9712^{\mathrm{T}}$ & $=\mathrm{CBS} 8297^{\mathrm{T}}$ & Dead tree & $\mathrm{Q}^{c}$ \\
\hline Cryptococcus ramirezgomezianus JCM $1460^{\mathrm{T}} \nleftarrow$ & $\begin{array}{l}=\text { CBS } 2839^{\mathrm{T}}=\mathrm{IJFM} 502^{\mathrm{T}} \\
=\text { NRRL Y- } 2478^{\mathrm{T}}\end{array}$ & Rotten toadstool & $\mathrm{Q}^{d}$ \\
\hline
\end{tabular}

* As determined by: $a$, Yamada \& Kondo (1972); b, Vancanneyt et al. (1994); c, Nakase et al. (1996); $d$, this study.

$\dagger$ Type strain of Torula humicola Daszewska.

† Syntype of Sporobolomyces albidus Ramírez Gómez.

ND, Not determined. 


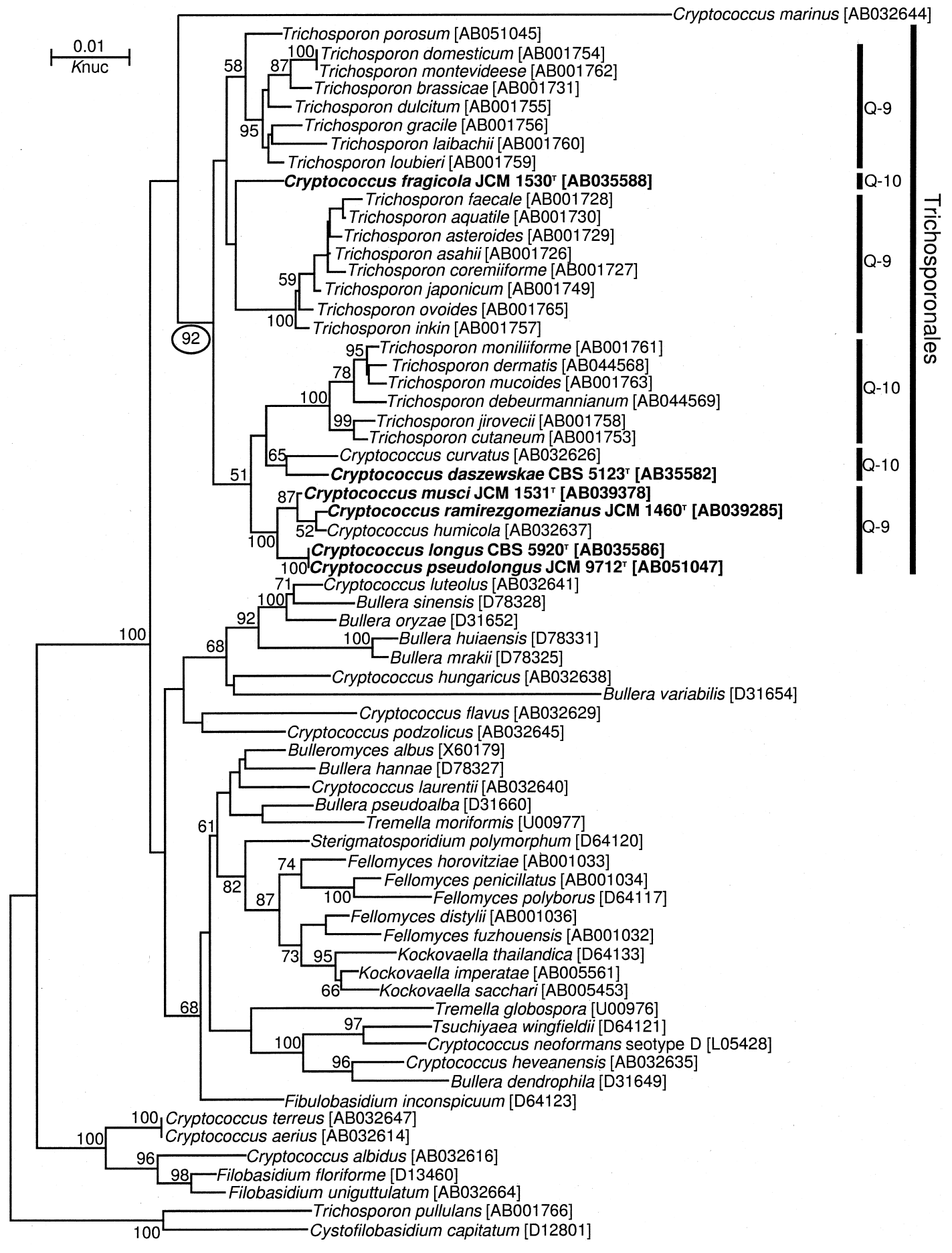

Fig. 1. Phylogenetic tree of the Cryptococcus humicola complex and related species based on 185 rDNA sequences. Numerals represent percentages from 100 replicate bootstrap samplings (values less than $50 \%$ are not shown). Sequences were retrieved from the DDBJ/GenBank/EMBL databases under the accession numbers indicated.

cluding the 5.8S rDNA of Cryptococcus sp. JCM $9712^{\mathrm{T}}$ and Trichosporon porosum JCM $1458^{\mathrm{T}}$, were determined directly using PCR products according to the method of Sugita \& Nakase (1999). Reference sequences used for the phylogenetic study were obtained from the DDBJ/GenBank/ EMBL database (Fig. 1). Sequences generated were aligned with related species using the CLUSTAL w computer program version 1.8 (Thompson et al., 1994) and checked visually. The phylogenetic tree was constructed from the evolutionary distance data according to Kimura (1980) using the neighbour-joining method (Saitou \& Nei, 1987) and the PHYLIP $3.573 \mathrm{c}$ computer program. Sites where gaps existed 
in any sequences were excluded. Bootstrap analyses (Felsenstein, 1985) were performed from 100 random resamplings.

\section{RESULTS AND DISCUSSION}

\section{Reclassification of the C. humicola complex}

The $C$. humicola strains used in this study occupied diverged positions in the order Trichosporonales (Fig. 1). Strain JCM $1530^{\mathrm{T}}$ was also placed in the Trichosporonales, but its phylogenetic position was not reliable because of a low bootstrap value. This strain was isolated from a strawberry (Nakase \& Komagata, 1971) and contained Q-10 as the major ubiquinone (Yamada \& Kondo, 1972). Since no other strains have been reported to be phylogenetically close to this strain, we concluded that strain JCM $1530^{\mathrm{T}}$ represents a distinct species.

Strain CBS $5123^{\mathrm{T}}$ constituted a cluster with C. curvatus (bootstrap 65\%). One of the Trichosporon clusters, which included Trichosporon cutaneum (de Beurmann et al.) Ota, occurred at a position adjacent to this cluster, but its bootstrap value was low. The similarity of $18 \mathrm{~S}$ rDNA sequences between CBS $5123^{\mathrm{T}}$ and $C$. curvatus $\mathrm{JCM} 1532^{\mathrm{T}}$ was $98.8 \%$. The similarity in the ITS region was reported to be less than $90 \%$ (Sugita et $a l ., 2000)$. In view of these facts and because of physiological and biochemical differences, we concluded that strain CBS $5123^{\mathrm{T}}$ represented a species distinct from $C$. curvatus. With respect to the major ubiquinone, this cluster is a ubiquinone Q-10 cluster.

Strains JCM $1460^{\mathrm{T}}$, JCM $1531^{\mathrm{T}}$, CBS $5920^{\mathrm{T}}$ and JCM $9712^{\mathrm{T}}$ were clustered with $C$. humicola $\mathrm{JCM} 1457^{\mathrm{T}}$. This cluster contains only Q-9 strains, since CBS $5920^{\mathrm{T}}$ and $\mathrm{JCM} 1460^{\mathrm{T}}$ were investigated and found to be Q9 in this study. With respect to sequence analysis of the $18 \mathrm{~S}$ rDNA, a close relationship was detected between JCM $1460^{\mathrm{T}}$ and JCM $1531^{\mathrm{T}}$. Moreover, CBS $5920^{\mathrm{T}}$ and JCM $9712^{\mathrm{T}}$ were also found to be closely related. In the ITS region, the ITS2 sequences of JCM $1460^{\mathrm{T}}$ and $\mathrm{JCM} 1531^{\mathrm{T}}$ were identical and five base substitutions and ten base deletions or insertions were detected in the ITS1 region (total $115 \mathrm{bp}$; similarity, $87 \cdot 0 \%$ ), as shown in Fig. 2. Thus, the overall similarity of the ITS region between JCM $1460^{\mathrm{T}}$ and JCM $1531^{\mathrm{T}}$ was $95.8 \%$, as discussed previously (Sugita et al., 2000). In the case of CBS $5920^{\mathrm{T}}$ and JCM $9712^{\mathrm{T}}$, the sequence similarity of ITS1, ITS2 and the overall ITS

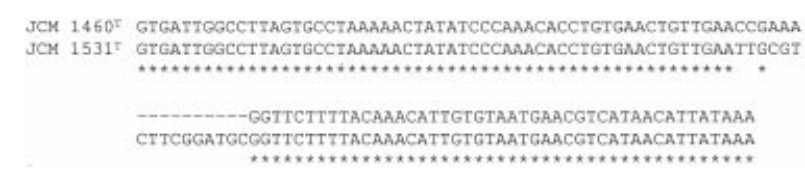

Fig. 2. Primary sequences of the ITS1 regions of JCM $1460^{\top}$ and JCM $1531^{\top}$. Gaps are indicated by dashes. Asterisks indicate identical nucleotides between the two aligned sequences.
JCM $9712^{\mathrm{T}}$ GATCTCTCAACCAATAGAGTTTTCTATTGGCTTGGATCTGGGTGTTGCGAG-CGATCGCT CBS $5920^{T}$ GATCTCTCAACCAATAGAGTTTTCTATTGGCTTGGATCTGGGTGCTGCGAAACAATCGCT

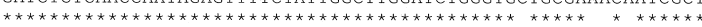

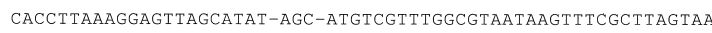
CACCTTAAAGGAGTTAGCAACTAAGCGATGTCGTCCGACGTAATAAGTTTCGTCTGGTAA ******

ATCGACAAGGCT--TTGCTTCTAATCGTCTTTTGACTTTTTTGAC

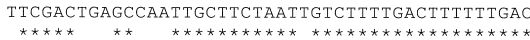

Fig. 3. Primary sequences of the ITS2 regions of CBS $5920^{\top}$ and JCM $9712^{\top}$. Gaps are indicated by dashes. Asterisks indicate identical nucleotides between the two aligned sequences.

region was 100, $85 \cdot 4$ and $90 \cdot 6 \%$, respectively (Fig. 3). According to the species concept of Sugita et al. (1999), these strains would be separate species. To confirm this, we carried out DNA-DNA reassociation experiments and found that the strains examined represented five distinct species (Table 2).

On the basis of D1/D2 sequences of the 26S rDNA, Fell et al. (2000) showed that $C$. humicola was closely related to the Trichosporonales, but did not include this species in this order because of the low bootstrap value. However, on the basis of $18 \mathrm{~S}$ rDNA sequences, Takashima \& Nakase (1999) reported the inclusion of this species in the Trichosporon lineage. In this paper, we also obtained a high bootstrap value $(92 \%)$ for this lineage after the reclassification of the $C$. humicola complex and confirmed the inclusion of $C$. humicola in the Trichosporonales. The order Trichosporonales contains the Trichosporon species [with the exception of Trichosporon pullulans (Lindner) Diddens et Lodder], C. curvatus and C. humicola. The diagnostic criterion between the genera Trichosporon and Cryptococcus in the order is whether or not arthroconidia are produced. Furthermore, strain JCM $1460^{\mathrm{T}}$, which is a syntype of Sporobolomyces albidus Ramírez Gómez and was reported to produce ballistoconidia, has been treated as belonging to the genus Cryptococcus, because the ballistoconidium-forming activity of this species is supposed to have been lost (Fell \& StatzellTallman, 1998). The taxonomic significance of ballistoconidium-forming activity was discussed in several papers (Fell et al., 2000; Hamamoto \& Nakase, 2000; Takashima \& Nakase, 1999). Based on these aspects and also because our novel species do not produce arthroconidia, we tentatively place these species in the genus Cryptococcus and here propose five novel species, Cryptococcus daszewskae, Cryptococcus fragicola, Cryptococcus longus, Cryptococcus musci and Cryptococcus pseudolongus. Concerning a syntype of S. albidus (JCM $1460^{\mathrm{T}}$ ), since the name Cryptococcus albidus (Saito) C. E. Skinner has been recognized for a distinct species within the genus Cryptococcus, the name Cryptococcus ramirezgomezianus nom. nov. is proposed for $S$. albidus Ramírez Gómez. These species are not phylogenetically close to the authentic Cryptococcus species, since the neotype species of the genus, Cryptococcus neoformans, occurs in another lineage 
Table 2. DNA relatedness among $C$. humicola and phylogenetically closely related species

\begin{tabular}{|c|c|c|c|c|c|c|}
\hline \multirow[t]{2}{*}{ Strain } & \multirow{2}{*}{ DNA G $+C$ content $(\mathrm{mol} \%)$} & \multicolumn{5}{|c|}{ Relative binding (\%) of labelled DNA from: } \\
\hline & & 1 & 5 & 6 & 7 & 8 \\
\hline 1. C. humicola JCM $1457^{\mathrm{T}}$ & $58 \cdot 7$ & 100 & 33 & 27 & 21 & 11 \\
\hline 2. C. humicola JCM 1459 & $59 \cdot 8$ & 88 & - & - & - & - \\
\hline 3. C. humicola JCM 1461 & $58 \cdot 7$ & 92 & - & - & - & - \\
\hline 4. C. humicola JCM 9575 & $59 \cdot 8$ & 98 & - & - & - & - \\
\hline 5. C. longus CBS $5920^{\mathrm{T}}$ & $60 \cdot 6$ & 41 & 100 & 25 & 35 & 13 \\
\hline 6. C. musci $\mathrm{JCM} 1531^{\mathrm{T}}$ & $58 \cdot 8$ & 46 & 36 & 100 & 28 & 32 \\
\hline 7. C. pseudolongus JCM $9712^{\mathrm{T}}$ & $59 \cdot 1$ & 40 & 46 & 26 & 100 & 32 \\
\hline 8. C. ramirezgomezianus $\mathrm{JCM} 1460^{\mathrm{T}}$ & $60 \cdot 7$ & 35 & 20 & 32 & 15 & 100 \\
\hline
\end{tabular}

(Fell et al., 2000; Takashima \& Nakase, 1999). These novel species will be transferred to the appropriate genus when it is eventually proposed.

Practically, C. fragicola differs from all other Cryptococcus species by its incapacity to assimilate cadaverine dihydrochloride. C. daszewskae is distinguished from C. curvatus because it is able to utilize melibiose and saccharate and unable to assimilate methyl $\alpha$-Dglucoside or salicin. C. humicola and the related species C. longus, C. musci, C. pseudolongus and C. ramirezgomezianus can be discriminated by their responses to several tests, namely assimilation of raffinose, hexadecane, butane-2,3-diol and sodium nitrite and growth at 30 and $35^{\circ} \mathrm{C}$, as shown in Table 3 .

\section{Taxonomic significance of ubiquinone in the Trichosporonales}

In the basidiomycetous yeasts, most species contain Q10 as the major ubiquinone and relatively few species are characterized by Q-8 or Q-9. Major ubiquinone types have been used as a chemotaxonomic criterion at the genus level; however, they have occasionally been shown to be inconsistent with the delimitation of some species. C. humicola and Leucosporidium scottii Fell et al. were reported as examples of such inconsistency (Yamada \& Kondo, 1972).

In this study, we determined the major ubiquinones of JCM $1460^{\mathrm{T}}$ and CBS $5920^{\mathrm{T}}$. Although C. humicola was reported to include both Q-9 and Q-10 strains, the phylogenetic tree (Fig. 1) clearly showed that the Q9 strains in the $C$. humicola complex were phylogenetically separated from the Q-10 strains. Sugita \& Nakase (1998) reported that the ubiquinone types were uniform in each phylogenetic cluster of Trichosporon species and that these types correlated with the serotypes of Trichosporon species. Our result also showed that the ubiquinone type of the species that make up the four major clusters were uniform, as shown in Fig. 1. These results suggest that the ubiquinone type, which corresponds to the phylogenetic relationships detected so far, is relevant as a taxonomic criterion in the Trichosporonales. In view of the phylogeny of the Trichosporonales, this order will probably be divided into several genera. The major ubiquinone type should be used as an important taxonomic criterion for this revision in combination with other characteristics.

\section{The ITS region as a marker for identification}

Sugita et al. (1999) observed that more than 99\% sequence similarity of the overall ITS region (ITS1 + ITS2) indicated the same species. Between phylogenetically closely related species, the sequence similarity of ITS1 was shown to be similar or slightly lower than that of ITS2 (e.g. Sugita et al., 2000; Takashima $\&$ Nakase, 2000). This region was believed to contain intervening sequences without function, but Musters et al. (1990) and van der Sande et al. (1992) reported that ITS2 was involved in the processing of rRNA. ITS1 was also reported to be involved in rRNA maturation (Lalev et al. 2000).

In this study, we found that the ITS2 sequences of JCM $5920^{\mathrm{T}}$ and JCM $9712^{\mathrm{T}}$ were identical, but $85.4 \%$ similarity was detected in ITS1 (overall similarity $90.6 \%$ ). In the case of JCM $1460^{\mathrm{T}}$ and $\mathrm{JCM} 1531^{\mathrm{T}}$, the sequence similarity of ITS1, ITS2 and the overall ITS region was $87 \cdot 0,100$ and $95 \cdot 8 \%$, respectively. The DNA relatedness values obtained indicated that each of these strains represented a separate species. Based on this approach, we concluded that identification based on ITS1 or ITS2 individually might be insignificant and that involvement of the 'overall' (total) ITS sequence is essential for correct identification as described by Sugita et al. (1999).

\section{Latin diagnosis of Cryptococcus daszewskae Takashima, Sugita, Shinoda et Nakase sp. nov.}

In liquido ' $\mathrm{YM}$ ', post dies 3 ad $25^{\circ} \mathrm{C}$, cellulae ovoideae, ellipsoideae aut elongatae, 2-8 $\times 3-12 \mu \mathrm{m}$, singulae, binae, aut in fasciculis, propagantes gemmarum blasticarum. Sedimentum formatur. Post unum mensem ad $17^{\circ} \mathrm{C}$, annulus repens, pellicula fragilis et completa, et sedimentum formantur. In agaro 'YM', post unum 
Table 3. Salient characteristics of the newly proposed species and related species

Species are identified as: 1, C. fragicola; 2, C. daszewskae; 3, C. curvatus; 4, C. longus; 5, C. musci; 6, C. pseudolongus; 7, C. ramirezgomezianus; $8, C$. humicola. Characters are scored as: + , positive; - , negative; L, latent; W, weak; LW, latent and weak; $\mathrm{v}$, variable. NA, Not available.

\begin{tabular}{|c|c|c|c|c|c|c|c|c|}
\hline Characteristic & 1 & 2 & 3 & 4 & 5 & 6 & 7 & 8 \\
\hline \multicolumn{9}{|c|}{ Assimilation of carbon compounds } \\
\hline L-Sorbose & + & $\mathrm{L}$ & LW & + & + & + & + & + \\
\hline Trehalose & + & + & LW & + & + & + & + & + \\
\hline Melibiose & + & + & - & + & + & + & + & + \\
\hline Raffinose & + & + & + & $\mathrm{L}$ & - & - & $\mathrm{L}$ & $\mathrm{V}$ \\
\hline Melezitose & + & + & $\mathrm{L}$ & + & + & + & + & + \\
\hline D-Arabinose & + & + & LW & + & + & + & + & + \\
\hline L-Rhamnose & + & + & $\mathrm{L}$ & + & + & + & + & + \\
\hline Ethanol & $\mathrm{L}$ & + & + & + & + & + & + & $\mathrm{LW} / \mathrm{W} /+$ \\
\hline Erythritol & + & + & $\mathrm{L}$ & + & + & + & + & + \\
\hline Ribitol & + & + & $\mathrm{L}$ & + & + & + & + & + \\
\hline Methyl $\alpha$-D-glucoside & + & - & $\mathrm{L}$ & + & + & + & + & + \\
\hline Salicin & + & - & + & + & + & + & + & + \\
\hline Glucono- $\delta$-lactone & - & - & LW & + & + & + & + & + \\
\hline Inositol & + & + & LW & + & + & + & + & + \\
\hline Hexadecane & - & - & & $\mathrm{L}$ & $\mathrm{L}$ & - & - & $-/ \mathrm{LW}$ \\
\hline Saccharate & + & + & - & $\mathrm{L}$ & + & + & + & + \\
\hline Xylitol & $\mathrm{L}$ & + & LW & + & + & + & + & + \\
\hline L-Arabitol & $\mathrm{L}$ & + & $\mathrm{L}$ & + & + & + & + & + \\
\hline Butane-2,3-diol & LW & $\mathrm{L}$ & - & + & + & + & - & $\mathrm{LW} / \mathrm{W} / \mathrm{L}$ \\
\hline \multicolumn{9}{|c|}{ Assimilation of nitrogen compounds } \\
\hline Sodium nitrite & - & - & NA & - & + & - & - & $\mathrm{V}$ \\
\hline Ethylamine hydrochloride & + & - & NA & + & + & + & + & + \\
\hline Cadaverine dihydrochloride & - & + & NA & + & + & + & + & + \\
\hline Growth temperature $\left({ }^{\circ} \mathrm{C}\right)$ & $30+, 35-$ & $35+$ & NA & $30+, 35-$ & $30+, 35-$ & $30+, 35-$ & $30+, 35-$ & $35+$ \\
\hline Major ubiquinone & Q-10 & Q-10 & Q-10 & Q-9 & Q-9 & Q-9 & Q-9 & Q-9 \\
\hline
\end{tabular}

mensem ad $17^{\circ} \mathrm{C}$, cultura albo-flava aut luteola, glabra, nitida, mollis, margo glabra. In cultura Dalmau plate, post dies 27 ad $17^{\circ} \mathrm{C}$, pseudomycelia et mycelia flexuosa formantur. Fermentatio nulla. Glucosum, galactosum, L-sorbosum (lente), sucrosum, maltosum, cellobiosum, trehalosum, lactosum, melibiosum, raffinosum, melezitosum, amylum solubile, D-xylosum, L-arabinosum, D-arabinosum, D-ribosum, L-rhamnosum, D-glucosaminum, $N$-acetylum D-glucosaminum, ethanolum, glycerolum, erythritolum, ribitolum, galactitolum, D-mannitolum, D-glucitolum, acidum D-gluconicum, acidum 2-ketogluconicum, acidum 5-ketogluconicum, acidum DL-lacticum, acidum succinicum, acidum citricum, inositolum, acidum saccharicum, xylitolum, L-arabitolum, 1,2-propanediolum, 2,3-butanediolum (lente), acidum Dglucuronicum et acidum D-galacturonicum assimilantur, autem inulinum, methanolum, methylum $\alpha$-D-glucosidum, salicinum, glucono- $\delta$-lactonum et hexadecanum non assimilantur. L-Lysinum et cadaverinum assimilantur, autem kalium nitricum, natrium nitrosum et ethylaminum non assimilantur. Maxima temperatura crescentiae: $36-37^{\circ} \mathrm{C}$. Ad crescentiam thiaminum necessarium est. Diazonium caeruleum B positivum. Proportio molaris guanini + cytosini in acido deoxyribo- nucleico: $59 \cdot 4 \mathrm{~mol} \%$. Ubiquinonum majus: Q-10. Xylosum in cellulis presens. Typus CBS $5123^{\mathrm{T}}(=\mathrm{JCM}$ $11166^{\mathrm{T}}=\mathrm{MUCL} 30649^{\mathrm{T}}$ ) ex cute conservatur in collectionibus culturarum quas Centraalbureau voor Schimmelcultures, Trajectum ad Rhenum, The Netherlands, sustentat.

\section{Description of Cryptococcus daszewskae Takashima, Sugita, Shinoda et Nakase sp. nov.}

Cryptococcus daszewskae (das.zew'ska.e. N.L. gen. n. daszewskae in honour of $\mathrm{W}$. Daszewska for his contribution to yeast taxonomy, especially the original description of $C$. humicola).

After $3 \mathrm{~d}$ of growth in YM broth at $25^{\circ} \mathrm{C}$, vegetative cells are oval, ellipsoidal or elongate, $2-8 \times 3-12 \mu \mathrm{m}$, single, in pairs or in groups, reproducing by budding (Fig. 4a). A sediment is formed. After 1 month at $17^{\circ} \mathrm{C}$, a creeping and complete ring, a complete fragile pellicle and a sediment are present. On YM agar, after 1 month at $17^{\circ} \mathrm{C}$, streak cultures are yellowish white to pale yellow, shining to semi-shining, smooth and soft and have an entire margin. In Dalmau plate culture on 

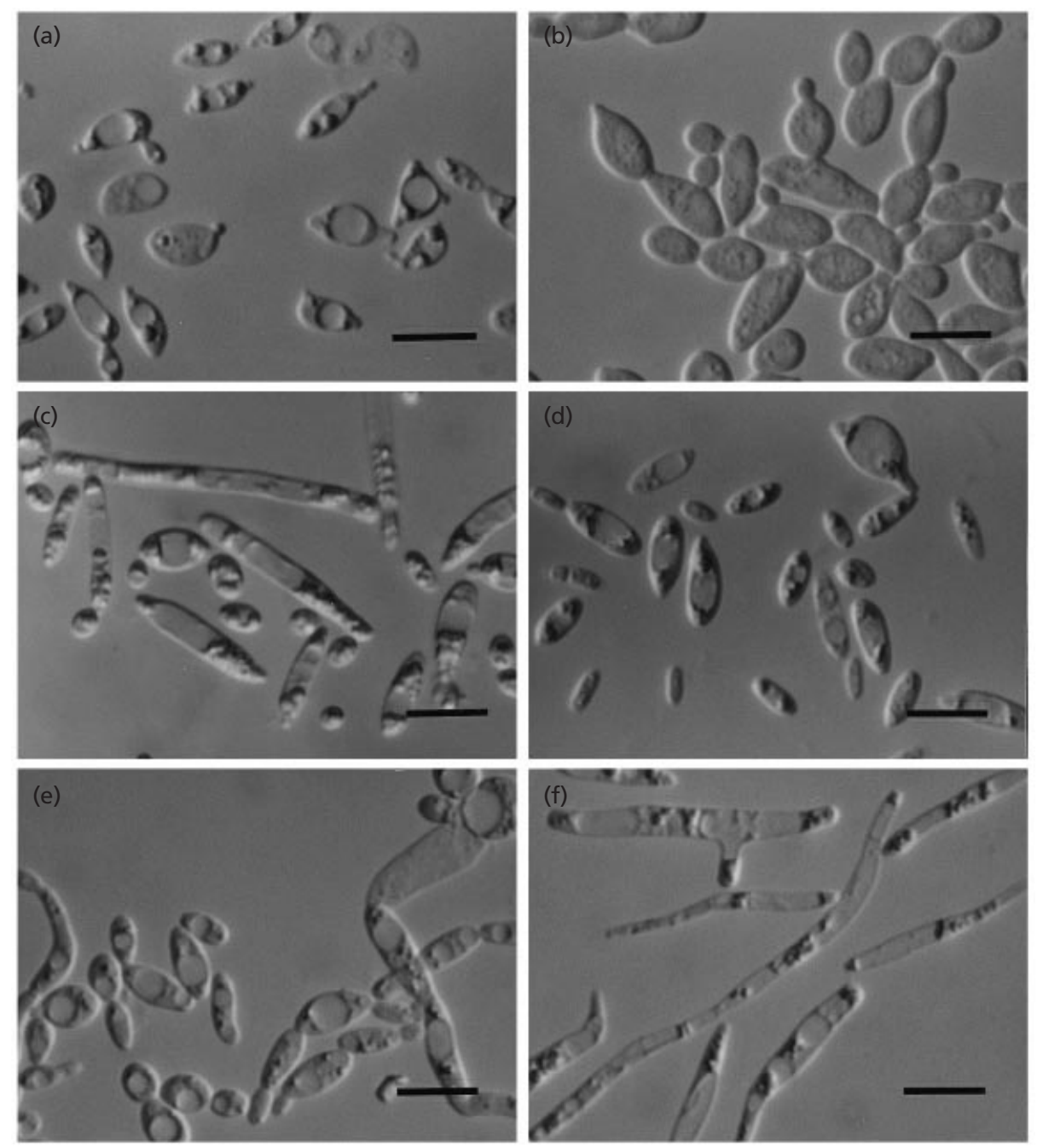

Fig. 4. Vegetative cells grown in $\mathrm{YM}$ broth for $3 \mathrm{~d}$ at $25^{\circ} \mathrm{C}$. (a) Cryptococcus daszewskae CBS 5123'; (b) Cryptococcus fragicola JCM 1530 ${ }^{\top}$; (c) Cryptococcus longus CBS 5920 ${ }^{\top}$; (d) Cryptococcus musci JCM 1531 $1^{\top}$; (e) Cryptococcus pseudolongus JCM $9712^{\top}$; (f) Cryptococcus ramirezgomezianus JCM $1460^{\top}$. Bars, $10 \mu \mathrm{m}$.

cornmeal agar, after $27 \mathrm{~d}$ at $17^{\circ} \mathrm{C}$, pseudomycelia and mycelia are formed. Mycelia are flexunose and branched at wide angles. The physiological and chemotaxonomic characteristics are summarized in Table 4.

The type strain, CBS 5123 ${ }^{\mathrm{T}}$ (= JCM $11166^{\mathrm{T}}=$ MUCL $30649^{\mathrm{T}}$ ), isolated from skin and deposited by $\mathrm{E}$. Friedrich (strain no. 652) in June 1962, is maintained in the Centraalbureau voor Schimmelcultures, Utrecht, The Netherlands.

\section{Latin diagnosis of Cryptococcus fragicola Takashima, Sugita, Shinoda et Nakase sp. nov.}

In liquido ' $\mathrm{YM}$ ', post dies 3 ad $25^{\circ} \mathrm{C}$, cellulae ovoideae, ellipsoideae aut elongatae, 2-12 $\times 2-18 \mu \mathrm{m}$, singulae, binae, aut in fasciculis, propagantes gemmarum blasticarum. Sedimentum formatur. Post unum mensem ad $17^{\circ} \mathrm{C}$, annulus incompleta, insula, et sedimentum for- mantur. In agaro 'YM', post unum mensem ad $17^{\circ} \mathrm{C}$, cultura luteola, glabra, nitida, mollis, margo fimbriata. In cultura Dalmau plate, post dies 13 ad $17^{\circ} \mathrm{C}$, pseudomycelia, et mycelia flexuosa et conidiogenae formantur. Fermentatio nulla. Glucosum, galactosum, L-sorbosum, sucrosum, maltosum, cellobiosum, trehalosum, lactosum, melibiosum, raffinosum, melezitosum, inulinum (lente et exiguum), amylum solubile, Dxylosum, L-arabinosum, D-arabinosum, D-ribosum, Lrhamnosum, D-glucosaminum, $N$-acetylum D-glucosaminum, ethanolum (lente), glycerolum, erythritolum, ribitolum, galactitolum, D-mannitolum, D-glucitolum, methylum $\alpha$-D-glucosidum, salicinum, acidum D-gluconicum, acidum 2-ketogluconicum, acidum 5-ketogluconicum, acidum DL-lacticum, acidum succinicum, acidum citricum, inositolum, acidum saccharicum, xylitolum (lente), L-arabitolum (lente), 1,2-propanediolum, 2,3-butanediolum (lente et exiguum), acidum D-glucuronicum et acidum D-galacturonicum assimilantur, 
Table 4. Physiological and chemotaxonomic characterization of the newly proposed species

All strains listed are negative for assimilation of methanol. All strains listed are positive for assimilation of glucose, galactose, sucrose, maltose, cellobiose, trehalose, lactose, melibiose, melezitose, soluble starch, D-xylose, L-arabinose, D-arabinose, D-ribose, L-rhamnose, D-glucosamine, $N$-acetyl D-glucosamine, glycerol, erythritol, ribitol, galactitol, D-mannitol, D-glucitol, D-gluconate, 2-ketogluconic acid, 5-ketogluconic acid, DL-lactic acid, succinic acid, citric acid, inositol, propane-1,2-diol, D-glucuronic acid and D-galacturonic acid. Characters are scored as: +, positive; -, negative; L, latent; LW, latent and weak.

\begin{tabular}{|c|c|c|c|c|c|}
\hline Character & $\begin{array}{c}\text { C.daszewskae } \\
\text { CBS } 5123^{\mathrm{T}}\end{array}$ & $\begin{array}{l}\text { C. fragicola } \\
\text { JCM 1530T }\end{array}$ & $\begin{array}{c}\text { C. longus } \\
\text { CBS 5920T }\end{array}$ & $\begin{array}{c}\text { C. musci } \\
\text { JCM } 1531^{\mathrm{T}}\end{array}$ & $\begin{array}{l}\text { C. pseudolongus } \\
{\text { JCM } 9712^{\mathrm{T}}}^{-}\end{array}$ \\
\hline Fermentation & - & - & - & - & - \\
\hline \multicolumn{6}{|l|}{ Assimilation of: } \\
\hline L-Sorbose & $\mathrm{L}$ & + & + & + & + \\
\hline Raffinose & + & + & $\mathrm{L}$ & - & - \\
\hline Inulin & - & LW & - & - & - \\
\hline Ethanol & + & $\mathrm{L}$ & + & + & + \\
\hline Methyl $\alpha$-D-glucoside & - & + & + & + & + \\
\hline Salicin & - & + & + & + & + \\
\hline Glucono- $\delta$-lactone & - & - & + & + & + \\
\hline Hexadecane & - & - & $\mathrm{L}$ & $\mathrm{L}$ & - \\
\hline Saccharate & + & + & $\mathrm{L}$ & + & + \\
\hline Xylitol & + & $\mathrm{L}$ & + & + & + \\
\hline L-Arabitol & + & $\mathrm{L}$ & + & + & + \\
\hline Butane-2,3-diol & $\mathrm{L}$ & LW & + & + & + \\
\hline Ammonium sulfate & + & + & + & + & + \\
\hline Potassium nitrate & - & - & - & - & - \\
\hline Sodium nitrite & - & - & - & + & - \\
\hline Ethylamine hydrochloride & - & + & + & + & + \\
\hline L-Lysine hydrochloride & + & + & + & + & + \\
\hline Cadaverine dihydrochloride & + & - & + & + & + \\
\hline Vitamins required & Thiamin & Thiamin & Thiamin & Thiamin & Thiamin \\
\hline Maximum growth temperature $\left({ }^{\circ} \mathrm{C}\right)$ & $36-37$ & $30-31$ & $31-32$ & $33-34$ & $32-33$ \\
\hline Production of starch-like substances & + & + & + & + & + \\
\hline Growth in $50 \%(\mathrm{w} / \mathrm{w})$ glucose/yeast extract agar & - & - & - & - & - \\
\hline Urease reaction & + & + & + & + & + \\
\hline Hydrolysis of fat & - & - & - & - & - \\
\hline Acid production from glucose & - & - & - & - & - \\
\hline Diazonium blue $\mathrm{B}$ reaction & + & + & + & + & + \\
\hline Liquefaction of gelatin & - & - & - & - & - \\
\hline $\mathrm{G}+\mathrm{C}$ content of nuclear DNA $(\mathrm{mol} \%)^{*}$ & $59 \cdot 4^{\mathrm{a}}$ & $58 \cdot 8^{\mathrm{b}}$ & $60 \cdot 6$ & $58 \cdot 8$ & $59 \cdot 1$ \\
\hline Major ubiquinone & Q-10 & Q-10 & Q-9 & Q-9 & Q-9 \\
\hline Xylose in the cell & Present & Present & Present & Present & Present \\
\hline
\end{tabular}

* Data not determined in this study were taken from: $a$, Nakase \& Komagata (1971); $b$, Vancanneyt et al. (1994).

autem methanolum, glucono- $\delta$-lactonum et hexadecanum non assimilantur. Ethylaminum et L-lysinum assimilantur, autem kalium nitricum, natrium nitrosum et cadaverinum non assimilantur. Maxima temperatura crescentiae: $30-31{ }^{\circ} \mathrm{C}$. Ad crescentiam thiaminum necessarium est. Diazonium caeruleum B positivum. Proportio molaris guanini+cytosini in acido deoxyribonucleico: $58.8 \mathrm{~mol} \%$. Ubiquinonum majus: Q-10. Xylosum in cellulis presens. Typus JCM 1530 ${ }^{\mathrm{T}}$ (= CBS $8898^{\mathrm{T}}$ ), ex fragis, Akihabara, Tokyo, Japonia, 1962, T. Nakase et K. Komagata (originaliter ut YV-170), conservatur in collectionibus culturarum quas Japan Collection of Microorganisms, Saitama, Japonia, sustentat.

\section{Description of Cryptococcus fragicola Takashima, Sugita, Shinoda et Nakase sp. nov.}

Cryptococcus fragicola (fra.gi'co.la. L. n. fragum the strawberry; L. suff. -cola inhabitant, dweller; N.L. n. fragicola inhabitant of strawberries, referring to the isolation of the type strain).

After $3 \mathrm{~d}$ of growth in YM broth at $25^{\circ} \mathrm{C}$, the vegetative cells are oval, ellipsoidal or elongate, $2-12 \times 2-18 \mu \mathrm{m}$, single, in pairs or in groups, reproducing by budding (Fig. 4b). A sediment is formed. After 1 month at $17^{\circ} \mathrm{C}$, an incomplete ring, islets and a sediment are present. After 1 month of growth on YM agar at $17^{\circ} \mathrm{C}$, the streak culture is pale yellow, 
shining to semi-shining, smooth and soft and has a fimbriate margin. In Dalmau plate culture on cornmeal agar, after $13 \mathrm{~d}$ at $17^{\circ} \mathrm{C}$, pseudomycelia and mycelia are formed. Mycelia are flexunose and produce conidia. Physiological and chemotaxonomic characteristics are summarized in Table 4.

The type strain, JCM $1530^{\mathrm{T}}$ ( = CBS $8898^{\mathrm{T}}$ ) (originally YV-170), isolated from a strawberry collected at a market in Akihabara, Tokyo, Japan, by T. Nakase and K. Komagata in April 1962, is maintained in the Japan Collection of Microorganisms, Saitama, Japan.

\section{Latin diagnosis of Cryptococcus longus Takashima, Sugita, Shinoda et Nakase sp. nov.}

In liquido 'YM', post dies 3 ad $25^{\circ} \mathrm{C}$, cellulae ovoideae, ellipsoideae, elongatae aut cylindraceae, 2.2-7.5 × 2.5$30 \mu \mathrm{m}$, singulae, binae, aut in fasciculis, propagantes gemmarum blasticarum. Sedimentum formatur. Post unum mensem ad $17^{\circ} \mathrm{C}$, annulus repens, pellicula fragilis et completa, et sedimentum formantur. In agaro ' $\mathrm{YM}$ ', post unum mensem ad $17^{\circ} \mathrm{C}$, cultura luteola aut griseoflava, rugosa aut cerebriformis, semi-nitida aut hebetata, mollis, margo fimbriata. In cultura Dalmau plate, post dies 13 ad $17^{\circ} \mathrm{C}$, pseudomycelia, et mycelia flexuosa et cymosa formantur. Fermentatio nulla. Glucosum, galactosum, L-sorbosum, sucrosum, maltosum, cellobiosum, trehalosum, lactosum, melibiosum, raffinosum (lente), melezitosum, amylum solubile, D-xylosum, L-arabinosum, D-arabinosum, D-ribosum, L-rhamnosum, D-glucosaminum, $N$-acetylum D-glucosaminum, ethanolum, glycerolum, erythritolum, ribitolum, galactitolum, D-mannitolum, D-glucitolum, methylum $\alpha$-D-glucosidum, salicinum, glucono- $\delta$-lactonum, acidum D-gluconicum, acidum 2-ketogluconicum, acidum 5-ketogluconicum, acidum DL-lacticum, acidum succinicum, acidum citricum, inositolum, hexadecanum (lente), acidum saccharicum (lente), xylitolum, L-arabitolum, 1,2-propanediolum, 2,3-butanediolum, acidum D-glucuronicum et acidum D-galacturonicum assimilantur, autem inulinum et methanolum non assimilantur. Ethylaminum, L-lysinum et cadaverinum assimilantur, autem kalium nitricum et natrium nitrosum non assimilantur. Maxima temperatura crescentiae: $31-32{ }^{\circ} \mathrm{C}$. Ad crescentiam thiaminum necessarium est. Diazonium caeruleum B positivum. Proportio molaris guanini + cytosini in acido deoxyribonucleico: $60.6 \mathrm{~mol} \%$. Ubiquinonum majus: Q-9. Xylosum in cellulis presens. Typus: CBS $5920^{\mathrm{T}}(=\mathrm{JCM}$ $11167^{\mathrm{T}}=$ MUCL $30690^{\mathrm{T}}$ ), ex solutione vegeto radio $\mathrm{pH} 2.0$ conservatur in collectionibus culturarum quas 'Centraalbureau voor Schimmelcultures', Trajectum ad Rhenum, The Netherlands, sustentat.

\section{Description of Cryptococcus longus Takashima, Sugita, Shinoda et Nakase sp. nov.}

Cryptococcus longus (lon'gus. L. adj. longus long, referring to the distinctive morphology of the cells).

After $3 \mathrm{~d}$ of growth in $\mathrm{YM}$ broth at $25^{\circ} \mathrm{C}$, the vegetative cells are oval, ellipsoidal, elongate or cyl- indrical, $2 \cdot 2-7 \cdot 5 \times 2 \cdot 5-30 \mu \mathrm{m}$, single, in pairs or in groups, reproducing by budding (Fig. 4c). A sediment is formed. After 1 month at $17^{\circ} \mathrm{C}$, a creeping and complete ring, a complete fragile pellicle and a sediment are present. On YM agar, after 1 month of growth at $17^{\circ} \mathrm{C}$, the streak culture is pale yellow to greyish yellow, matt to semi-shining, wrinkled and cerebriform near the bottom, soft and has a fimbriate margin. In Dalmau plate culture on cornmeal agar, after $13 \mathrm{~d}$ at $17^{\circ} \mathrm{C}$, pseudomycelia and mycelia are formed. Mycelia are flexunose and cymose branching and produce conidia. Physiological and chemotaxonomic characteristics are summarized in Table 4.

The type strain, CBS 5920 $\left(=\right.$ JCM $11167^{\mathrm{T}}=$ MUCL $30690^{\mathrm{T}}$ ), isolated from radioactive solution at $\mathrm{pH} \mathrm{2,}$ Delft, The Netherlands, and deposited by R. Kokke, no. $070668 \mathrm{Co} 9$, in July 1968, is maintained in the Centraalbureau voor Schimmelcultures, Utrecht, The Netherlands.

\section{Latin diagnosis of Cryptococcus musci Takashima, Sugita, Shinoda et Nakase sp. nov.}

In liquido ' $\mathrm{YM}$ ', post dies 3 ad $25^{\circ} \mathrm{C}$, cellulae ovoideae, ellipsoideae, aut elongatae, $2-10 \times 2-15 \mu \mathrm{m}$, singulae, binae, aut in fasciculis, propagantes gemmarum blasticarum. Sedimentum formatur. Post unum mensem ad $17^{\circ} \mathrm{C}$, annulus repens, pellicula fragilis et completa, et sedimentum formantur. In agaro 'YM', post unum mensem ad $17^{\circ} \mathrm{C}$, cultura griseoflava, farinosa et cerebriformis, hebetata, mollis, margo fimbriata. In cultura Dalmau plate, post dies 13 ad $17^{\circ} \mathrm{C}$, pseudomycelia, et mycelia flexuosa et cymosa formantur. Fermentatio nulla. Glucosum, galactosum, L-sorbosum, sucrosum, maltosum, cellobiosum, trehalosum, lactosum, melibiosum, melezitosum, amylum solubile, D-xylosum, L-arabinosum, D-arabinosum, D-ribosum, L-rhamnosum, D-glucosaminum, $N$-acetylum D-glucosaminum, ethanolum, glycerolum, erythritolum, ribitolum, galactitolum, D-mannitolum, D-glucitolum, acidum D-gluconicum, methylum $\alpha$-D-glucosidum, salicinum, glucono- $\delta$-lactonum, acidum 2-ketogluconicum, acidum 5-ketogluconicum, acidum DL-lacticum, acidum succinicum, acidum citricum, inositolum, hexadecanum (lente), acidum saccharicum, xylitolum, L-arabitolum, 1,2-propanediolum, 2,3-butanediolum, acidum D-glucuronicum et acidum D-galacturonicum assimilantur, autem raffinosum, inulinum et methanolum non assimilantur. Natrium nitrosum, ethylaminum, L-lysinum et cadaverinum assimilantur, autem kalium nitricum non assimilantur. Maxima temperatura crescentiae: 33-34 ${ }^{\circ} \mathrm{C} . \quad$ Ad crescentiam thiaminum necessarium est. Diazonium caeruleum B positivum. Proportio molaris guanini + cytosini in acido deoxyribonucleico: $58.8 \mathrm{~mol} \%$. Ubiquinonum majus: Q-9. Xylosum in cellulis presens. Typus: JCM $1531^{\mathrm{T}}\left(=\mathrm{CBS} 8899^{\mathrm{T}}\right)$, ex musco, Hase-dera, Kurayoshi, Tottori, Japonia, 1963, $\mathrm{T}$. Nakase et K. Komagata (originaliter ut M-9-2), conservatur in collectionibus culturarum quas 'Japan Collection of Microorganisms', Saitama, Japonia, sustentat. 
Description of Cryptococcus musci Takashima, Sugita, Shinoda et Nakase sp. nov.

Cryptococcus musci (mus'ci. L. gen. n. musci of moss, from which the type strain was isolated).

After $3 \mathrm{~d}$ of growth at $25^{\circ} \mathrm{C}$ in YM broth, vegetative cells are oval, ellipsoidal or elongate, $2-10 \times 2-15 \mu \mathrm{m}$, single, in pairs or in groups, reproducing by budding (Fig. 4d). A sediment is formed. After 1 month at $17^{\circ} \mathrm{C}$, a creeping and complete ring, a complete fragile pellicle and a sediment are present. On YM agar, after 1 month of growth at $17^{\circ} \mathrm{C}$, the streak culture is greyish yellow, matt, farinose and cerebriform, soft and has a fimbriate margin. In Dalmau plate culture on cornmeal agar, after $13 \mathrm{~d}$ at $17^{\circ} \mathrm{C}$, pseudomycelia and mycelia are formed. Mycelia are flexunose and cymose branching and produce conidia. Physiological and chemotaxonomic characteristics are summarized in Table 4.

The type strain, JCM $1531^{\mathrm{T}}\left(=\mathrm{CBS} 8899^{\mathrm{T}}\right.$ ) (originally M-9-2), isolated from moss collected at Hase-dera, a temple in Kurayoshi, Tottori, Japan, in December 1963 by T. Nakase and K. Komagata, is maintained in the Japan Collection of Microorganisms, Saitama, Japan.

\section{Latin diagnosis of Cryptococcus pseudolongus Takashima, Sugita, Shinoda et Nakase sp. nov.}

In liquido 'YM', post dies 3 ad $25^{\circ} \mathrm{C}$, cellulae ovoideae, ellipsoideae, elongatae aut cylindraceae, 1.5-17 $\times 2$ $23 \mu \mathrm{m}$, singulae, binae, aut in fasciculis, propagantes gemmarum blasticarum. Sedimentum formatur. Post unum mensem ad $17^{\circ} \mathrm{C}$, annulus repens, pellicula fragilis et completa, et sedimentum formantur. In agaro ' $\mathrm{YM}$ ', post unum mensem ad $17^{\circ} \mathrm{C}$, cultura luteola, glabra, semi-nidida, mollis, margo fimbriata. In cultura Dalmau plate, post dies 13 ad $17^{\circ} \mathrm{C}$, pseudomycelia, et mycelia flexuosa et cymosa formantur. Fermentatio nulla. Glucosum, galactosum, L-sorbosum, sucrosum, maltosum, cellobiosum, trehalosum, lactosum, melibiosum, melezitosum, amylum solubile, D-xylosum, L-arabinosum, D-arabinosum, D-ribosum, L-rhamnosum, D-glucosaminum, $N$-acetylum D-glucosaminum, ethanolum, glycerolum, erythritolum, ribitolum, galactitolum, D-mannitolum, D-glucitolum, acidum D-gluconicum, methylum $\alpha$-D-glucosidum, salicinum, glucono- $\delta$-lactonum, acidum 2-ketogluconicum, acidum 5-ketogluconicum, acidum DL-lacticum, acidum succinicum, acidum citricum, inositolum, acidum saccharicum, xylitolum, L-arabitolum, 1,2-propanediolum, 2,3-butanediolum, acidum D-glucuronicum et acidum D-galacturonicum assimilantur, autem raffinosum, inulinum, methanolum et hexadecanum non assimilantur. Ethylaminum, L-lysinum et cadaverinum assimilantur, autem natrium nitrosum et kalium nitricum non assimilantur. Maxima temperatura crescentiae: $32-33{ }^{\circ} \mathrm{C}$. Ad crescentiam thiaminum necessarium est. Diazonium caeruleum B positivum. Proportio molaris guanini+cytosini in acido deoxyribonucleico: $59 \cdot 1 \mathrm{~mol} \%$. Ubiquinonum majus: Q-9.
Xylosum in cellulis presens. Typus: JCM 9712 ${ }^{\mathrm{T}}(=\mathrm{CBS}$ $\left.8297^{\mathrm{T}}\right)$, ex ligno emortuo, Myooh-in-ji, Kusado, Fukuyama, Hiroshima, Japonia, 1990, T. Hatano et $\mathrm{S}$. Fukui (originaliter ut KO-7), conservatur in collectionibus culturarum quas 'Japan Collection of Microorganisms', Saitama, Japonia, sustentat.

\section{Description of Cryptococcus pseudolongus Takashima, Sugita, Shinoda et Nakase sp. nov.}

Cryptococcus pseudolongus (pseu.do.lon'gus. Gr. adj. pseudes false; L. adj. longus long; N.L. adj. pseudolongus a false longus, referring to the similarity of the morphology and other characters to those of Cryptococcus longus).

After $3 \mathrm{~d}$ of growth in $\mathrm{YM}$ broth at $25^{\circ} \mathrm{C}$, vegetative cells are oval, ellipsoidal, elongate or cylindrical, $1 \cdot 5-17 \times 2-23 \mu \mathrm{m}$, single, in pairs or in groups, reproducing by budding (Fig. 4e). A sediment is formed. After 1 month at $17^{\circ} \mathrm{C}$, a creeping and complete ring, a complete fragile pellicle and a sediment are present. After 1 month of growth on YM agar at $17^{\circ} \mathrm{C}$, the streak culture is pale yellow, semi-shining, smooth, soft and has a fimbriate margin. In Dalmau plate culture on cornmeal agar, after $13 \mathrm{~d}$ at $17^{\circ} \mathrm{C}$, pseudomycelia and mycelia are formed. Mycelia are flexunose and cymose branching and produce conidia. Physiological and chemotaxonomic characteristics are summarized in Table 4.

The type strain, JCM $9712^{\mathrm{T}}\left(=\mathrm{CBS} 8297^{\mathrm{T}}\right.$ ) (originally $\mathrm{KO}-7$ ), isolated from a dead tree in Myooh-in temple, Kusado, Fukuyama-shi, Hiroshima by T. Hatano and S. Fukui in 1990, is maintained in the Japan Collection of Microorganisms, Saitama, Japan.

\section{Description of Cryptococcus ramirezgomezianus Takashima, Sugita, Shinoda et Nakase nom. nov.}

Cryptococcus ramirezgomezianus (ra.mi'rez.go'me.zi. a.nus. N.L. gen. n. ramirezgomezianus in honour of C. Ramírez Gómez for his contributions to yeast taxonomy, especially his original description of Sporobolomyces albidus).

三Sporobolomyces albidus Ramírez Gómez in Microbiol Esp 10, 238, 1957 [non Cryptococcus albidus (Saito) C. E. Skinner in Am Midl Natur 43, 249, 1950].

The epithet albidus can not be used under the genus Cryptococcus because of the presence of $C$. albidus (Saito) C. E. Skinner. Therefore, the new name Cryptococcus ramirezgomezianus is herein given.

A micrograph of vegetative cells grown in YM broth for $3 \mathrm{~d}$ at $25^{\circ} \mathrm{C}$ is shown in Fig. 4(f). The following characteristics are added to the description of Ramírez Gómez (1957). Assimilates L-sorbose, cellobiose, trehalose, lactose, melibiose, raffinose (latent), melezitose, soluble starch, D-xylose, L-arabinose, D-arabinose, D-ribose, L-rhamnose, D-glucosamine, $N$-acetyl D-glucosamine, ethanol, glycerol, erythritol, 
ribitol, galactitol, D-mannitol, D-glucitol, methyl $\alpha$-Dglucoside, salicin, glucono- $\delta$-lactone, D-gluconate, 2 ketogluconic acid, 5-ketogluconic acid, DL-lactic acid, succinic acid, citric acid, inositol, saccharate, xylitol, L-arabitol, propane-1,2-diol, D-glucuronic acid and D-galacturonic acid. Does not assimilate inulin, methanol, hexadecane or butane-2,3-diol. Assimilates ethylamine hydrochloride, L-lysine hydrochloride and cadaverine dihydrochloride. Does not assimilate sodium nitrite. Thiamin is required for growth. Starch-like substances are produced. Growth does not occur on $50 \%$ (w/w) glucose/yeast extract agar. Urease-positive. Does not liquefy gelatin. Does not hydrolyse fat. Does not produce acid from glucose. The diazonium blue $\mathrm{B}$ reaction is positive. The $\mathrm{G}+\mathrm{C}$ content of nuclear DNA is $60.7 \mathrm{~mol} \%$ (by HPLC). The major ubiquinone is Q-9. Xylose is present in the cells. Maximum growth temperature is $33-34^{\circ} \mathrm{C}$. Physiological and chemotaxonomic characteristics are summarized in Table 4.

The type strain, IJFM $502^{\mathrm{T}}\left(=\mathrm{CBS} 2839^{\mathrm{T}}=\mathrm{JCM}\right.$ $1460^{\mathrm{T}}=$ NRRL Y $-2478^{\mathrm{T}}$ ), was isolated in France by C. Ramírez Gómez from a rotten toadstool (Fell \& Statzell-Tallman, 1998).

\section{ACKNOWLEDGEMENTS}

The authors sincerely thank Professor Emeritus Junta Sugiyama for writing the appropriate descriptions and also Dr James A. Barnett and Mr David Yarrow for help with references.

\section{REFERENCES}

Fell, J. W. \& Statzell-Tallman, A. (1998). Cryptococcus Vuillemin. In The Yeasts, a Taxonomic Study, 4th edn, pp. 742-767. Edited by C. P. Kurtzman \& J. W. Fell. Amsterdam: Elsevier.

Fell, J. W., Boekhout, T., Fonseca, A., Scorzetti, G. \& StatzellTallman, A. (2000). Biodiversity and systematics of basidiomycetous yeasts as determined by large-subunit rDNA D1/D2 domain sequence analysis. Int $J$ Syst Evol Microbiol 50, 1351-1371.

Felsenstein, J. (1985). Confidence limits on phylogenies: an approach using the bootstrap. Evolution 39, 783-791.

Hamamoto, M. \& Nakase, T. (1995). Ballistosporous yeasts found on the surface of plant materials collected in New Zealand. 1. Six new species in the genus Sporobolomyces. Antonie Leeuwenhoek 67, 151-171.

Hamamoto, M. \& Nakase, T. (2000). Phylogenetic analysis of the ballistoconidium-forming yeast genus Sporobolomyces based on 18S rDNA sequences. Int $J$ Syst Evol Microbiol 50, 1373-1380.

Kimura, M. (1980). A simple method for estimating evolutionary rates of base substitutions through comparative studies of nucleotide sequences. J Mol Evol 16, 111-120.

Komagata, K. \& Nakase, T. (1967). Microbiological studies on frozen foods. V. General properties of yeasts isolated from frozen foods. J Food Hyg Soc Japan 8, 53-57 (in Japanese).

Lalev, A. I., Abeyrathne, P. D. \& Nazar, R. N. (2000). Ribosomal RNA maturation in Schizosaccharomyces pombe is dependent on a large ribonucleoprotein complex of the internal transcribed spacer 1. J Mol Biol 302, 65-77.
Musters, W., Boon, K., van der Sande, C. A. F. M., van Heerikhuizen, H. \& Planta, R. J. (1990). Functional analysis of transcribed spacers of yeast ribosomal DNA. EMBO $J \mathbf{9}$, 3989-3996.

Nakase, T. \& Komagata, K. (1971). Significance of DNA base composition in the classification of yeast genus Candida. J Gen Appl Microbiol 17, 259-279.

Nakase, T. \& Suzuki, M. (1986). Bullera megalospora, a new species of yeast forming large ballistospores isolated from dead leaves of Oryza sativa, Miscanthus sinensis, and Sasa sp. in Japan. J Gen Appl Microbiol 32, 225-240.

Nakase, T., Suzuki, M., Hamamoto, M., Takashima, M., Hatano, T. \& Fukui, S. (1996). A taxonomic study on cellulolytic yeasts and yeast-like microorganisms isolated from Japan. II. The genus Cryptococcus. J Gen Appl Microbiol 42, 7-15.

Ramírez Gómez, C. (1957). Contribucion al estudio de la ecologia de las levaduras. I. Estudio de levaduras aisladas de hongos carnosos. Microbiol Esp 10, 215-247.

Saitou, N. \& Nei, M. (1987). The neighbor-joining method: a new method for reconstructing phylogenetic trees. Mol Biol Evol 4, 406-425.

van der Sande, C. A., Kwa, M., van Nues, R. W., van Heerikhuizen, H., Raué, H. A. \& Planta, R. J. (1992). Functional analysis of internal transcribed spacer 2 of Saccharomyces cerevisiae ribosomal DNA. J Mol Biol 223, 899-910.

Skinner, C. E. (1950). Generic name for imperfect yeasts, Cryptococcus or Torulopsis. Am Midl Natur 43, 242-250.

Sugita, T. \& Nakase, T. (1998). Molecular phylogenetic study of the basidiomycetous anamorphic yeast genus Trichosporon and related taxa based on small subunit ribosomal DNA sequences. Mycoscience 39, 7-13.

Sugita, T. \& Nakase, T. (1999). Non-universal usage of the leucine CUG codon and the molecular phylogeny of the genus Candida. Syst Appl Microbiol 22, 79-86.

Sugita, T., Nishikawa, A., Ikeda, R. \& Shinoda, T. (1999). Identification of medically relevant Trichosporon species based on sequences of internal transcribed spacer regions and construction of a database for Trichosporon identification. J Clin Microbiol 37, 1985-1993.

Sugita, T., Takashima, M., Ikeda, R., Nakase, T. \& Shinoda, T. (2000). Phylogenetic and taxonomic heterogeneity of Cryptococcus humicolus by analysis of the sequences of the internal transcribed spacer regions and $18 \mathrm{~S}$ rDNA, and the phylogenetic relationships of $C$. humicolus, $C$. curvatus, and the genus Trichosporon. Microbiol Immunol 44, 455-461.

Sugita, T., Takashima, M., Nakase, T., Ichikawa, T., Ikeda, R. \& Shinoda, T. (2001). Two new yeasts, Trichosporon debeurmannianum sp. nov. and Trichosporon dermatis sp. nov., transferred from the Cryptococcus humicola complex. Int J Syst Evol Microbiol 51, 1221-1228.

Takashima, M. \& Nakase, T. (1999). Molecular phylogeny of the genus Cryptococcus and related species based on the sequences of $18 \mathrm{~S}$ rDNA and internal transcribed spacer regions. Microbiol Cult Coll 15, 35-47.

Takashima, M. \& Nakase, T. (2000). Four new species of the genus Sporobolomyces isolated from leaves in Thailand. Mycoscience 41, 65-77.

Tamaoka, J. \& Komagata, K. (1984). Determination of DNA base composition by reversed-phase high-performance liquid chromatography. FEMS Microbiol Lett 25, 125-128.

Thompson, J. D., Higgins, D. G. \& Gibson, T. J. (1994). CLUSTAL $\mathrm{W}$ : improving the sensitivity of progressive multiple sequence 
alignment through sequence weighting, position-specific gap penalties and weight matrix choice. Nucleic Acids Res 22, 4673-4680.

Vancanneyt, M., Coopman, R., Tytgat, R., Hennebert, G. L. \& Kersters, K. (1994). Whole-cell protein patterns, DNA base compositions and coenzyme Q types in the yeast genus Cryptococcus Kützing and related taxa. Syst Appl Microbiol 17, 65-75.
Yamada, Y. \& Kondo, K. (1972). Taxonomic significance of coenzyme Q system in yeasts and yeast-like fungi. In Yeasts and Yeast-like Microorganisms in Medical Science, pp. 63-69. Edited by K. Iwata. Tokyo: University of Tokyo Press.

Yarrow, D. (1998). Methods for the isolation, maintenance and identification of yeasts. In The Yeasts, a Taxonomic Study, 4th edn, pp. 77-100. Edited by C. P. Kurtzman \& J. W. Fell. Amsterdam: Elsevier. 